\title{
Correction: Physicians' real-world experience with IDegLira: results of a European survey
}

Drummond R, Baru A, Dutkiewicz M, et al. Physicians' real-world experience with IDegLira: results of a European survey. BMJ Open Diabetes Research and Care 2018;6:e000531. doi: 10.1136/bmjdrc-2018-000531

The authors traced some formatting errors in figures 2 and 3 . The correct versions are now available below:

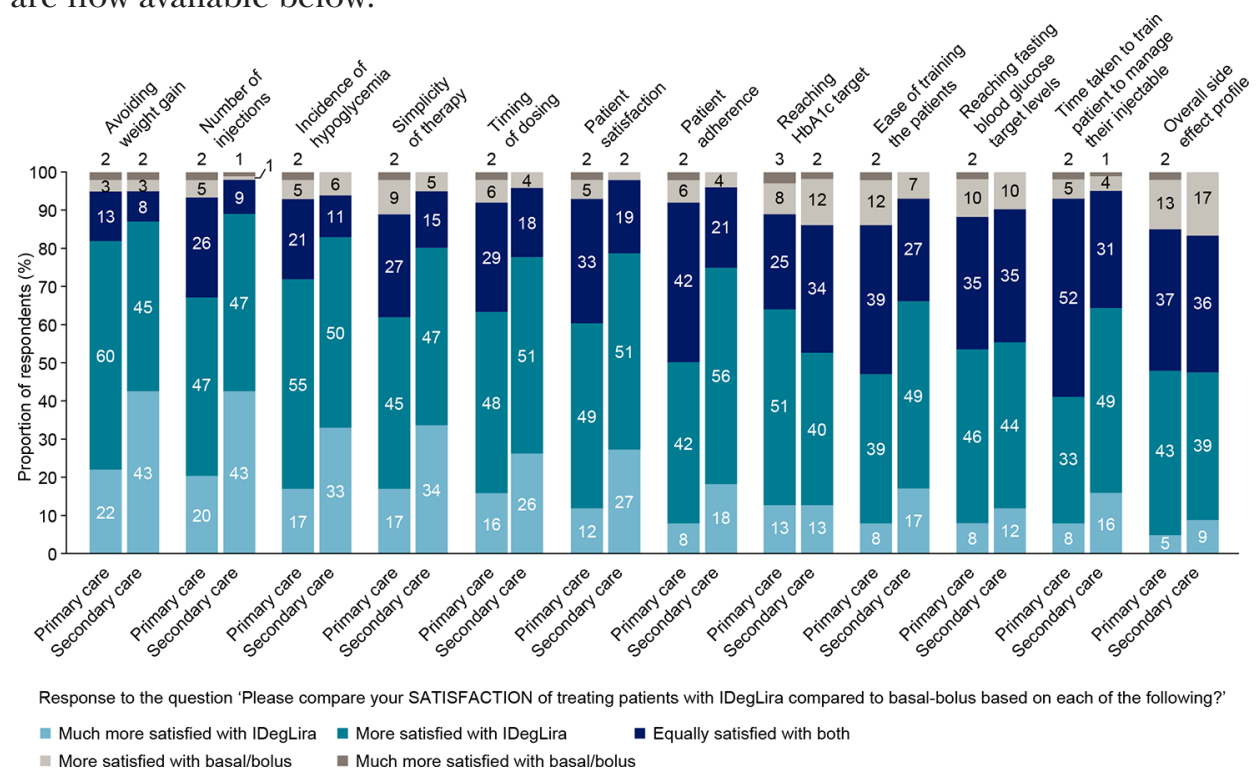

Figure 2 Satisfaction of respondents with IDegLira compared with basal-bolus. HbA1c, glycated hemoglobin; IDegLira, insulin degludec/liraglutide. 
A

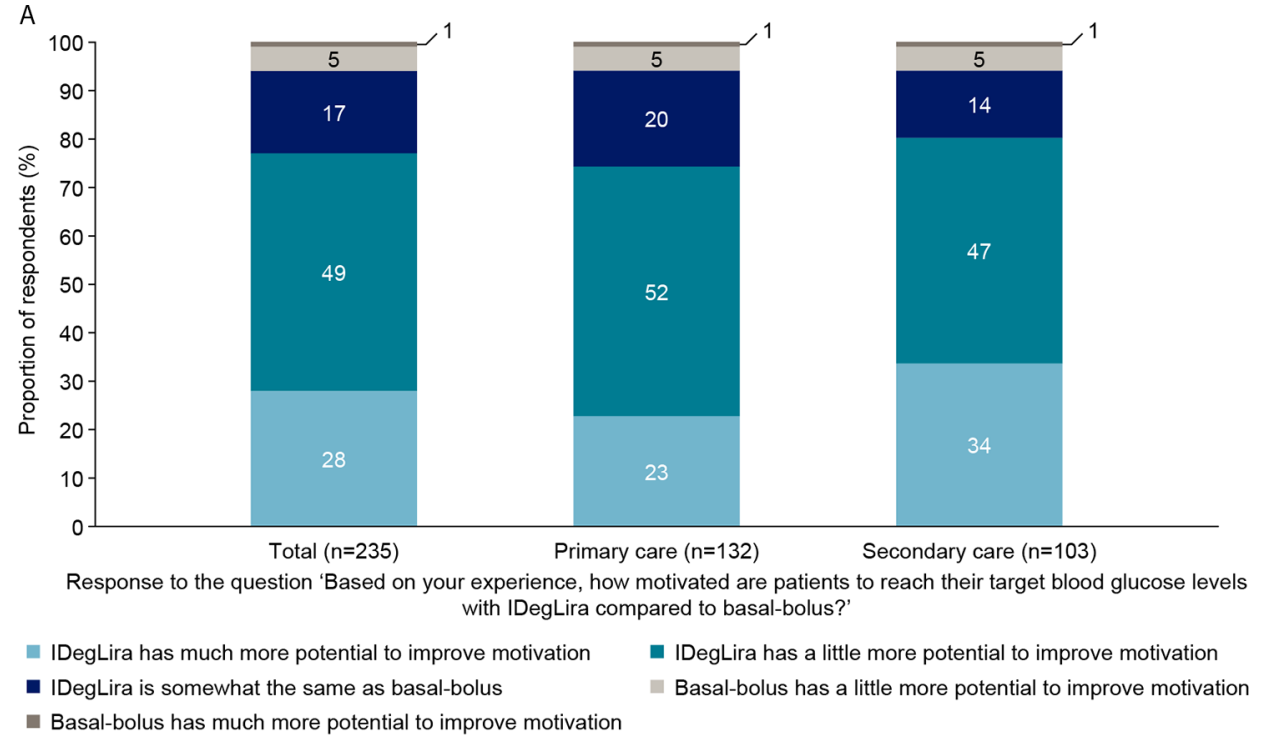

B $\begin{gathered}\text { Concern of patients } \\ \text { having hypoglycemia }\end{gathered}$

Concern of patients gaining weight

Concern of patients struggling with nausea and other $\mathrm{Gl}$ effects

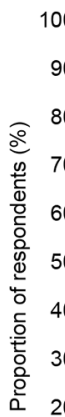

100
$90-$
$80-$
$70-$
$60-$
$50-$
$40-$
$30-$
$20-$
$10-$
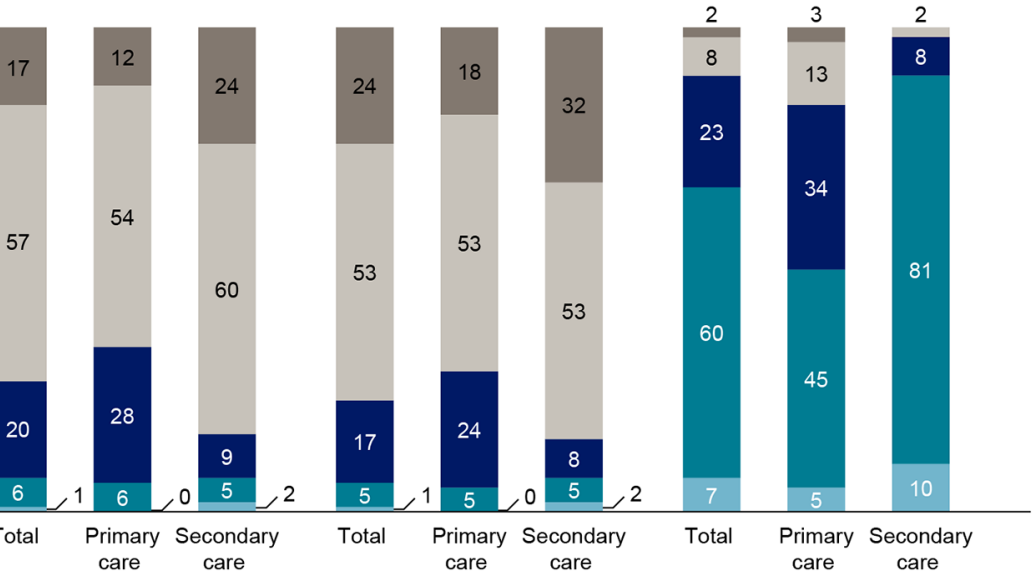

care care

care care

care care

Response to the question 'Based on your experience, what are your concerns for treating patients with basal-bolus compared with IDegLira?'

Much more concerned with IDegLira

More concerned with basal-bolus

- More concerned with IDegLira

Equally concerned with both

Much more concerned with basal-bolus

Figure 3 Respondents' perceptions on (A) the potential of IDegLira compared with basal-bolus therapy to improve patient motivation to reach their target blood glucose levels; and (B) concerns with IDegLira compared with basal-bolus therapy. GI, gastrointestinal; IDegLira, insulin degludec/liraglutide.

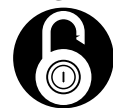

\section{OPEN ACCESS}

Open access This is an Open Access article distributed in accordance with the Creative Commons Attribution Non Commercial (CC BY-NC 4.0) license, which permits others to distribute, remix, adapt, build upon this work non-commercially, and license their derivative works on different terms, provided the original work is properly cited and the use is non-commercial. See: http://creativecommons.org/licenses/by-nc/4.0/

(C) Article author(s) (or their employer(s) unless otherwise stated in the text of the article) 2018. All rights reserved. No commercial use is permitted unless otherwise expressly granted.

BMJ Open Diab Res Care 2018;6:e000531corr1. doi:10.1136/bmjdrc-2018-000531corr1

D) Check for updates 